\section{Análise prospectiva das alterações imuno- hematológicas eritrocitárias em pacientes com leishmaniose visceral}

\begin{abstract}
A leishmaniose visceral (LV) é clinicamente caracterizada pela presença de febre, perda de peso e diarréia, acompanhada de anemia e hepatoesplenomegalia. Apesar de a anemia severa ser um achado freqüente na LV, os fatores envolvidos em sua patogênese são complexos. A presença de uma diminuição da sobrevida eritrocitária na fase aguda da doença tem sido consistentemente confirmada, bem como a presença de positividade para o teste de Coombs direto (TCD). Estudo prospectivo e seqüencial foi conduzido para investigar a presença de lgG associada à hemacia, por teste imunoenzimático (ELAT), observando sua importância no quadro anêmico, bem como sua associação com a presença de imunecomplexos (ICs) e fator reumatóide (FR) em pacientes com LV procedentes do Estado de Alagoas - Brasil. Foi realizado estudo prospectivo e sequencial em 67 amostras de sangue de pacientes com LV nas fases pré-tratamento, pós-tratamento e mais de três mêses após a cura. As amostras foram submetidas ao ELAT para quantificação de lgG/ hemácia, além de dosagem de hemoglobina $(\mathrm{Hb})$, pesquisa para TCD, ICs e FR. Os resultados deste estudo mostraram uma prevalência de TCD positivo ao dignóstico significantemente maior que a observada após 3 meses de cura $(32,8 \%$ vs $0 \%, p<0,0001)$. Usando uma técnica sensível (ELAT), encontramos que a quantidade de lgG/ hemácia estava aumentada (média $=311$ moléculas de IgG/hemácia) em $23,2 \%$ dos pacientes no diagnóstico. Esta quantidade de lgG/hemácia normalizou-se $(<25$ moléculas de IgG/hemácia) em todos os pacientes após o tratamento. A positividade para TCD e ELAT estava estatisticamente correlacionada com a presença de ICs e FR. Não foi encontrada associação positiva entre o grau de anemia dos pacientes e a presença de TCD, ELAT, ICs ou FR. O estudo sugere participação de processo
\end{abstract}

\section{A prospective study on erythrocytic immunohematological alterations in patients with visceral leishmaniasis}

The symptoms of visceral leishmaniasis (VL) include fever, weight loss and diarrhea, accompained by anemia and hepatosplenomegaly. Despite that anemia of increasingly severity is one of the most striking clinical features of VL, the factors involved in its pathogenesis are complex. Thus, a prospective study was conducted to investigate the presence of RBCassociated IgG in patients with VL from an endemic region (Alagoas) in Brazil. Repeated blood samples of 67 patients with VI were tested prospectively, at diagnosis and after treatment was completed and clinical cure was achieved. The prevalence of a positive direct antiglobulin test (DAT) at diagnosis was significantly higher than the prevalence of a positive DAT after 90 days of treatment $(32.8 \%$ vs $0 \%, p<0.0001)$. Using a enzyme-linked antiglobulin test (ELAT), we found that the amount of $\lg \mathrm{G} / \mathrm{RBC}$ was increased (mean $=311$ molecules of $\mathrm{lgG} / \mathrm{RBC}$ ) in $23.2 \%$ of patients at diagnosis. However, the amount of $\mathrm{lgG} / \mathrm{RBC}$ was normal ( $<25$ molecules of $\mathrm{lg} / \mathrm{RBC}$ ) in all patients tested after treatment. The positivity of both TCD and ELAT correlated with the presence of either circulating immune complexes $(\mathrm{ClC})$ or reumatoid factor $(\mathrm{RF})$. The data show that some patients with VL have increased amount of RBC-associated IgG and therefore, may be at increased risk for autoimmune hemolysis. However, futher studies are required to establish the role of $\mathrm{RBC}$ autoantibodies, CIC, and RF as contributing factors of the anemia seen in these patients.

Recebido para publicação em 6/4/99 
auto-imune em alguns casos, porém outros estudos clínicos futuros ainda se fazem necessários para confirmar a correlação entre mecanismo imune e anemia nos pacientes com LV.

Rosana Quintella Brandão Vilela

Tese apresentada à Escola Paulista de Medicina da Universidade Federal de São Paulo para obtenção do Título de Doutor.

São Paulo, SP, Brasil, 1995. 